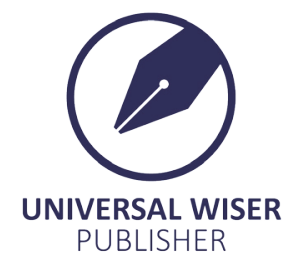

\title{
Platinum Nanoparticles: Synthesis Strategies and Applications
}

\author{
Ayushi Gautam ${ }^{1}$, Praveen Guleria ${ }^{1}$, Vineet Kumar ${ }^{2 *}$ \\ ${ }^{1}$ Department of Biotechnology, DAV University, Jalandhar, Punjab 144012, India \\ ${ }^{2}$ Department of Biotechnology, School of Bioengineering and Biosciences, Lovely Professional University, Phagwara, Punjab 144411, \\ India \\ E-mail: vineetkumar22@gmail.com
}

\begin{abstract}
Plantinum nanoparticles (Pt NPs) have huge potential as heterogeneous catalyst, chemiresistor coating material, nanomedicine, nanosensor, and electronic components along with various other industrial applications. Physical, chemical as well as biological methods are used for the synthesis of plantinum NPs. Physical methods depend upon the physical phenomenon for Pt NPs synthesis. Chemical methods involve one or other chemical reactions to prepare Pt NPs. Biological methods are preferred over other methods. Among all biological sources, use of plant extracts for Pt NPs synthesis is safe and cost-effective. Pt NPs have application in catalysis, electronics, nanodiagnosis and nanomedicine. Synthesis of diverse Pt NPs using different plant bioresource may be more useful for various in vivo applications in future.
\end{abstract}

Keywords: platinum nanoparticles, green synthesis, biological synthesis, plant extract

\section{Introduction}

The particles that have their one dimension atleast 1 to $1000 \mathrm{~nm}$, more specifically $1-100 \mathrm{~nm}$ are defined as nanoparticles (NPs). The diversity in NPs shape and size widens their area of application. The size, shape and surface coating stabilizing NPs are responsible for their unique properties. ${ }^{[1]}$ Due to nanorange size, the NPs possess large surface area and better penetration properties that are required for environmental, and in vivo applications. ${ }^{[2-6]}$ NPs have important in vivo biological applications in biomedical fluorescent labelling, drug delivery, detection of pathogens and pharmacological studies. ${ }^{[7-10]}$ Among various kinds of nanomaterials, Pt NPs are very useful due to their corrosion resistance and significant catalytic properties. ${ }^{[11]}$ Enhanced catalytic activity of Pt NPs as compared to their bulk counterparts can play an important role in the reduction of exhaust pollutant gases emitted from automobiles. Catalytic properties are also very useful for the generation of hydrogen fuel. ${ }^{[12,13]}$

The synthesis and characterization of NPs have been explored rigorously for the last 2 decades. Pt NPs are usually present in the form of suspension or colloid of Pt NPs in a fluid usually water. The size of Pt NPs like other metallic NPs are between 2-100 $\mathrm{nm}$ and can be manipulated by varying the reaction conditions. ${ }^{[14,15]}$ Synthesis of metallic NPs including Pt NPs is difficult due to their reactivity and agglomeration. The stability of Pt NPs is the primary requisite for various applications of Pt NPs. ${ }^{[16]}$ Pt NPs are widely used in the electronic industry for the manufacture of conductive thick film circuits and internal electrodes of multilayer ceramic capacitors. ${ }^{[17]}$ The NPs are also used in chemical hydrogenation reactions such as hydrogenation of o-chloronitrobenzene and cinnamaldehyde ${ }^{[18]}$ Cis-diammine-dichloro-Pt is metallic Pt compound which is significantly used as cancer drug.${ }^{[19]} \mathrm{Pt}$ NPs also have therapeutic application against cancer and cardiovascular diseases. ${ }^{[20,21]}$ However, with the expanding horizons of nanomaterial applications, there is growing concern regarding risk of toxicity at different trophic level through soil, air and water. ${ }^{[22]}$ In this review we highlight the different methods of Pt NPs synthesis, their adavnatges and disadvatages and applications in various fields in detail.

\section{Synthesis and characterization of Pt NPs}

The size, shape, surface covering and dispersion of Pt NPs are governed by their method of synthesis. These features can significantly be regulating the parameters and process of NPs synthesis. Following section describes the various identified and studied strategies of Pt NPs synthesis (Figure 1).

Copyright (C2020 Vineet Kumar, et al.

DOI: https://doi.org/10.37256/nat.122020286.70-86

This is an open-access article distributed under a CC BY license

(Creative Commons Attribution 4.0 International License)

https://creativecommons.org/licenses/by/4.0/ 


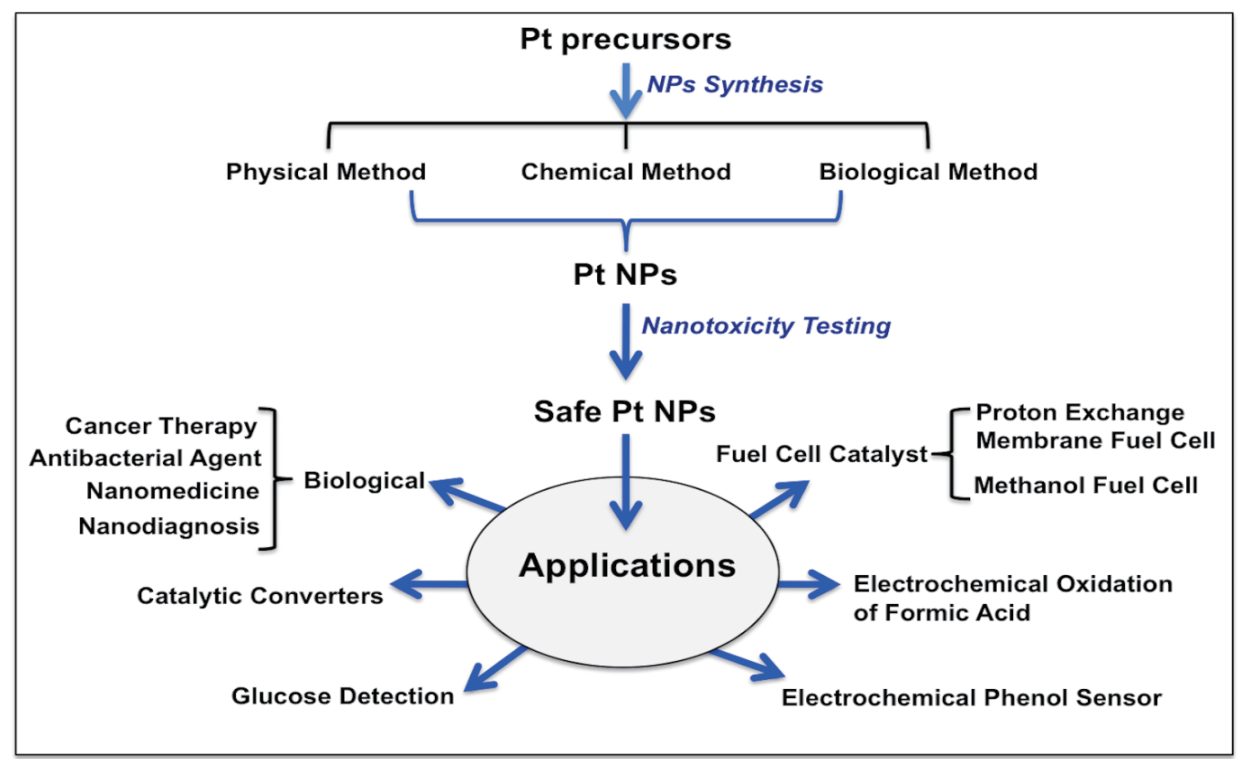

Figure 1. A schematic representation of steps for the production and utilization of Pt NPs containing various properties

\subsection{Physical methods of Pt NPs synthesis}

Various physical methods have already been reported for the preparation of metallic NPs. Some of the common physical methods of Pt NPs synthesis include laser ablation, ball milling, physical vapour deposition and ion sputtering. Following section describes use of these methods for the synthesis of Pt NPs of various morphologies.

In a simple method, heating chloroplatinic acid in a mufle furnance at $350{ }^{\circ} \mathrm{C}$ has been reported to form $2.5-3.3 \mathrm{~nm} \mathrm{Pt}$ NPs over silicon carbide-alumina layer. ${ }^{[23]}$ Neodymium yttrium aluminium garnet (Nd:YAG) laser based ablation method has been used to produce 8-9 $\mathrm{nm}$ Pt NPs in deionized water from PT plate. ${ }^{[24,25]}$ Likewise, Nd: YAG laser was reported to synthesize Pt NPs in ethanol and aqueous trisodium citrate medium. Ethanol led to the production of 7-9 nm Pt NPs, while comparatively larger 9-10 $\mathrm{nm}$ NPs were produced in aqueous trisodium citrate solution. ${ }^{[26]}$

Pt NPs of 5-20 nm were obtained by using PVD coater producing $700{ }^{\circ} \mathrm{C}$ for 90 minutes. ${ }^{[27]} \mathrm{Pt}$ NPs have been synthesized from Pt wire by plasma sputtering in water. Plasma derived high energy electrons and radicals bombarded Pt surface releasing Pt atoms leading to the synthesis of highly dispersed $2 \mathrm{~nm} \mathrm{Pt} \mathrm{NPs.}{ }^{[28]}$ Recently introduction of low pressure liquid as matrix with matrix sputtering was represented as a safer method for the synthesis and stabilization of $\mathrm{Pt}$ NPs. Use of polyethylene glycol as liquid matrix led to the synthesis of 0.9-1.4 nm sized NPs. The Pt NPs prepared through this method were stable in dispersion phase for a duration of 5 months (Figure 2). ${ }^{[29]}$
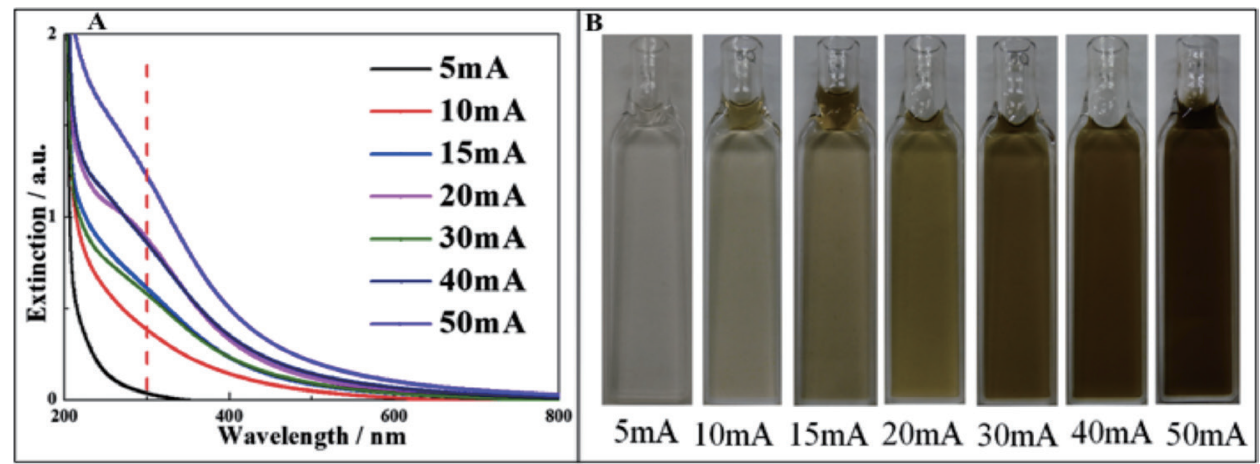

Figure 2. Pt NPs obtained by sputter deposition onto PEG. (A) UV-visible spectra of Pt NPs. Increase in peak intensity along the dotted red line indicates quantitative increase in Pt NPs synthesis with increase in sputtering current from 5 to $50 \mathrm{~mA}$. (B) Photograph of Pt NPs dispersions of PEG under room light (right) with different sputtering currents. The change in color of reaction mixtures from colorless to yellow and to dark brown with increase in sputtering current from 5 to $50 \mathrm{~mA}$ indicates quantitative increase in synthesis of Pt NPs. Color change acts as indicator of quantity of Pt NPs. "Reprinted with permission from (Deng et al., 2018) ${ }^{[29]}$. Copyright (2018) American Chemical Society."

Ball milling approach has been used for the production FePt NPs in hexane. Iron and Pt powder were ground in presence of oleic acid and oleylamine to form $4 \mathrm{~nm}$ FePt NPs using hardened steel balls. ${ }^{[30]}$ Similalry, PtFe nanocomposites 
were obtained by grinding iron nitrate, chloroplatinic acid and PEO-PPO-PEO, P123 in a screw-capped zirconia reactor containing four zirconia ball bearings. ${ }^{[31]}$

\subsection{Chemical synthesis}

Chemical methods has been used for the synthesis of Pt NPs in solutions phase as well as over the surface of a solid support. Support may be in the form of general supporting material like silica or even some nanomaterial like carbon nanotubes. Most of the chemical methods are easy and inexpensive. Pt NPs have been usually prepared by reduction of Pt metal precursor. Chloroplatinic acid, $\mathrm{H}_{2} \mathrm{PtCl}_{6}$ is one of the common precursors used for the chemical as well as biological synthesis of Pt NPs. The precursor is usually dissolved in an aqueous or organic liquid material. The conversion of dissolved precursor into solid NPs is done by introducing a reducing agent leading to a chemical conversion step. The most commonly used reducing agent for $\mathrm{H}_{2} \mathrm{PtCl}_{6}$ reduction is sodium borohydrate $\left(\mathrm{NaBH}_{4}\right) \cdot{ }^{[32,33]}$ Immediately after reduction of $\mathrm{H}_{2} \mathrm{PtCl}_{6}$ to Pt NPs, the NPs needs to be stabilized with surface stabilizing agents or surfactants. This step is critical to control the size and shape of metallic NPs including Pt NPs. Different methods have reported chemical preparation of Pt NPs with varying size, shape and surface covering. Pt NPs can also be synthesized by decomposition, displacement and electrochemical reactions. ${ }^{[34,35]}$

Very small 2-3 nm Pt NPs were produced and deposited over hollow aluminium oxide $\left(\mathrm{Al}_{2} \mathrm{O}_{3}\right)$ nanoplates prepared using $\mathrm{NaBH}_{4}$ as reducing agent. The synthesized nanocomposite material was used for oxidative conversion of harmful formaldehyde to carbon dioxide and water. ${ }^{[3,37,38]}$ Likewise, supercritical fluid chemical deposition method has also been used for the synthesis of Pt NPs over the carbon nanotubes surface. ${ }^{[39,40]}$ Synthesis of Pt NPs of size range 2.9-60 nm has been documented using chloroplatinic acid as precursor, formic acid as reducing agent, and polyvinylpyrrolidone as surfactant. The control over size was obtained by using different concentrations of reducing agent and surfactant. ${ }^{[41]}$ Use of ethylene glycol as solvent and reducing agent and time bound addition of polyvinyl pyrrolidone as surfactant has been reported to regulate the size of Pt NPs. Addition of precursor $\mathrm{H}_{2} \mathrm{PtCl}_{6}$ to preheated ethylene glycol followed by drop-bydrop addition of polyvinyl pyrrolidone was found to synthesize stable Pt NPs of size less than 10 nm within four hours of synthesis. The smaller amount of polyvinyl pyrrolidone addition assured Pt NPs size to be smaller, 7 nm. Further addition of polyvinyl pyrrolidone was found to inhibit the complete reduction of $\mathrm{PtCl}_{6}^{2-}$ perhaps due to formation of a stable complex. ${ }^{[42]}$ Sodium borohydrate mediated reduction of $\mathrm{Pt}$ precursor ions has been used in a microreactor system to synthesisze Pt NPs over carbon fibers surface. The microreactor system can adjust the flow rate to obtain desired size of Pt NPs at variable deposition rates. Polyvinyl alcohol was used as a surfactant. ${ }^{[43]}$ Increasing reaction temperature is well known to decrease the time required for a chemical process. Likewise, chemical synthesis of Pt NPs in a microractor could reduce time required for the synthesis from $40 \mathrm{~min}$ at $40{ }^{\circ} \mathrm{C}$ to few seconds at $105{ }^{\circ} \mathrm{C}$. In this study, vitamin $\mathrm{C}$ was used as reducing agent and polyvinyl pyrrolidone was used as surfactant..$^{[44]}$

UV light mediated photoreduction of hexachloroplatinate (IV) $\left(\mathrm{PtCl}_{6}{ }^{2-}\right)$ to Pt NPs by methanol has been reported. ${ }^{[45]}$ Likewise, photoreduction has been used to obtain monodisperse Pt NPs. In this method, poly(ethylenimine) (PEI) was used as surface stabilizing agent. ${ }^{[46]}$ Gamma radiation has also been explored for the reduction of Pt tetraammine to Pt NPs in the presence of stabilizer polyvinyl pyrrolidone. Radiation dose was used to control the size of NPs between 2.8 to 4.4 nm. ${ }^{\text {[47] }}$ Surfactant mediated synthesis of Pt NPs is useful for in vivo and environmental applications as it reduced the reactivity and hence toxicity of Pt NPs. Pt NPs synthesis has also been documented elsewhere in detail. Such Pt NPs are of specific interest for catalysis and electrochemical applications. ${ }^{[48]}$

Pt nanocubes, 5-7 nm and nano-octahedra 8-12 nm were obtained by reacting $\mathrm{H}_{2} \mathrm{PtCl}_{6}$ with silver nitrate. Silver ions were mainly responsible for controlling the size and shape of Pt NPs. ${ }^{[49]} \mathrm{Pt}$ NPs can also be prepared by decomposition, displacement and electrochemical reactions. ${ }^{[34,35]}$ Electrochemical method has also been employed for the synthesis of mesoporous Pt nanorods over the pores of mesoporous polycarbonate support. ${ }^{[50]}$

For the shape controlled synthesis of Pt NPs, polymeric stabilizers have commonly been used as surfactant. The degree of polymerization and concentration of the used stabilized polymer influences the size of colloidal NPs and their growth. However, control of NPs size is difficult to achieve. The shape and size of Pt NPs can be regulated by changing the concentration ratio of the capping polymer material to the Pt cations used in the reductive synthesis at room temperature. In such a study, Pt NPs of different shapes has been documented using different concentration ratio of capping agent, polyacrylate to precursor metal ion, Potassium tetrachloroplatinate(II). The capping agent: precursor ratio was varied between 1: 1 to 1: 5 to obtain tetrahedral, cubic, irregular-prismatic, icosahedral, and cubo-octahedral particle. ${ }^{[51]}$ So, Pt NPs of various shapes namely nanospheres, nanowires, truncated octahedral and nanocubes (Figure 3). ${ }^{[52,53,54,42,55]}$ 


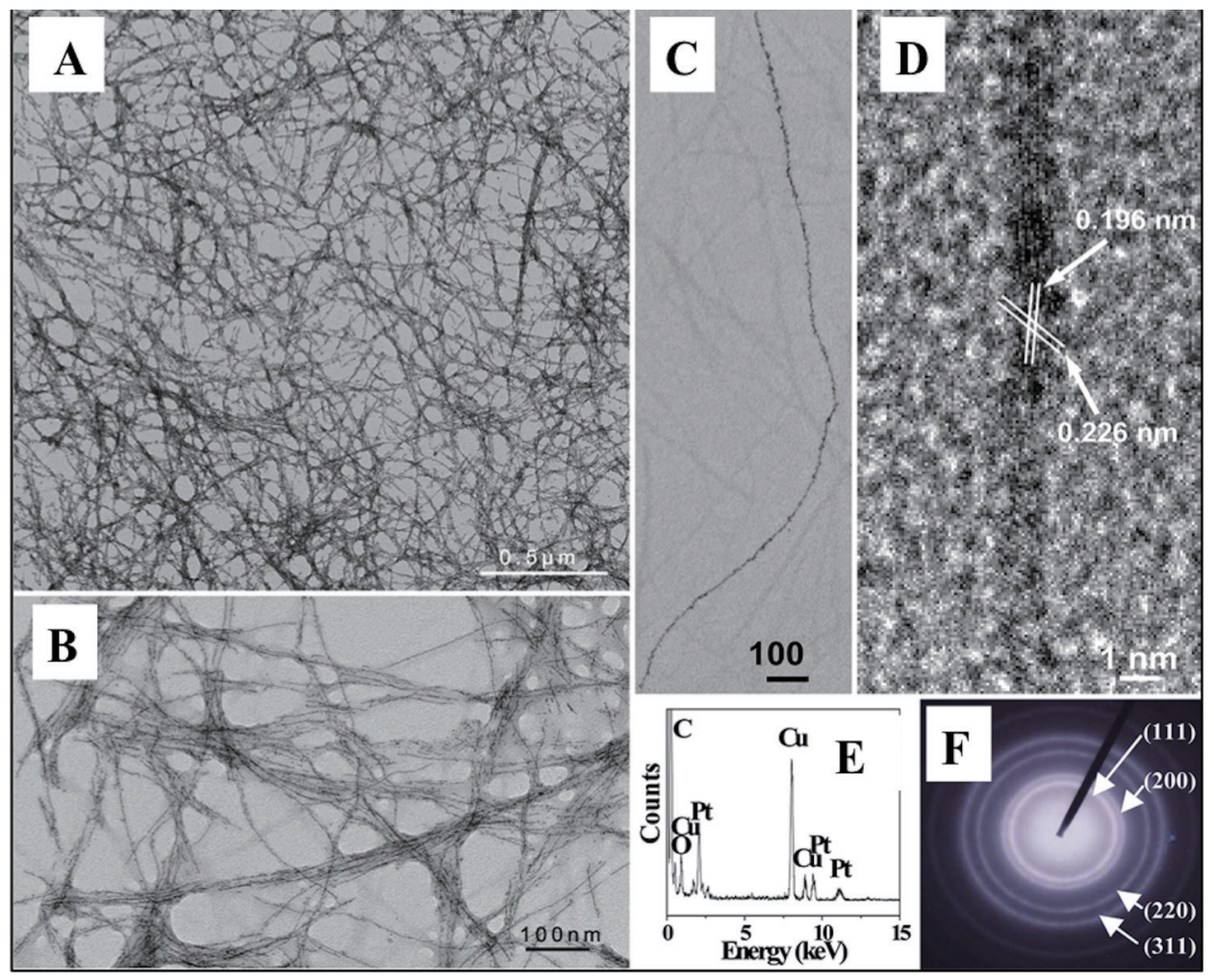

Figure 3. TEM characterisation of Highly uniform single-crystal ultrathin Pt nanowires (UTPtNWs). TEM images of UTPtNWs at diferent conditions: (A) Low magnification; (B) High magnification; (C) Single Pt nanowire and (D) HRTEM image of a single Pt nanowire. (E) EDS spectrum and (F) SAED pattern of UTPtNWs built using insulin amyloid fibrils (INSAFs). "Reprinted with permission from (Zhang et al., 2012)

${ }^{54}$. Copyright (2012) American Chemical Society."

\subsection{Biological synthesis}

Biological synthesis is a noble green process for the metallic NPs synthesis. Pt NPs can be synthesized by using unicellular and multicellular organisms. Various studies document the monodispersed and stable Pt NPs synthesis by bacteria, cyanobacteria, seaweeds, fungi and plants. ${ }^{[14,56]}$

\subsubsection{Bacteria mediated synthesis}

Bacteria produce different kind of enzymes and metabolites. These enzymes and metabolites act to reduce metal ions into NPs. However, the exact mechanism responsible for the synthesis of metallic NPs by bacterial enzyme is not completely known. Several studies document the probable role of cytochrome C3 and hydrogenase enzyme for the NPs synthesis. Enzymes have tendency to oxidise hydrogen or organic to induce metallic reduction of sulphate as a final electron acceptor. ${ }^{[57]}$ Enzyme produced by sulphate reducing bacteria has been used for the synthesis of Pt NPs. ${ }^{[58]}$ Sulphate reducing bacteria obtained from a biosulphidogenic reactor can potentially reduce Pt(IV) to Pt NPs. ${ }^{[59]}$ Use of a mixture of sulphate reducing bacteria is recommended over pure culture as it is less liable for contamination from other organisms.

${ }^{[60]}$ Cell-free extract of a consortium of sulfate-reducing bacteria has also been used for the syntheis of Pt NPs. ${ }^{[61]}$ In Streptomyces sp. mediated synthesis, amino acid moieties acts as reducing agents to synthesize Pt NPs. The NPs were 20$50 \mathrm{~nm}$ in size and possessed in vitro anticancer activity. ${ }^{[62]}$ Likewise, 2-3 nm Pt NPs can be obtained using Acinetobacter calcoaceticus. Proteins moieties are the key component responsible for the NPs synthsis. ${ }^{[63]}$ 


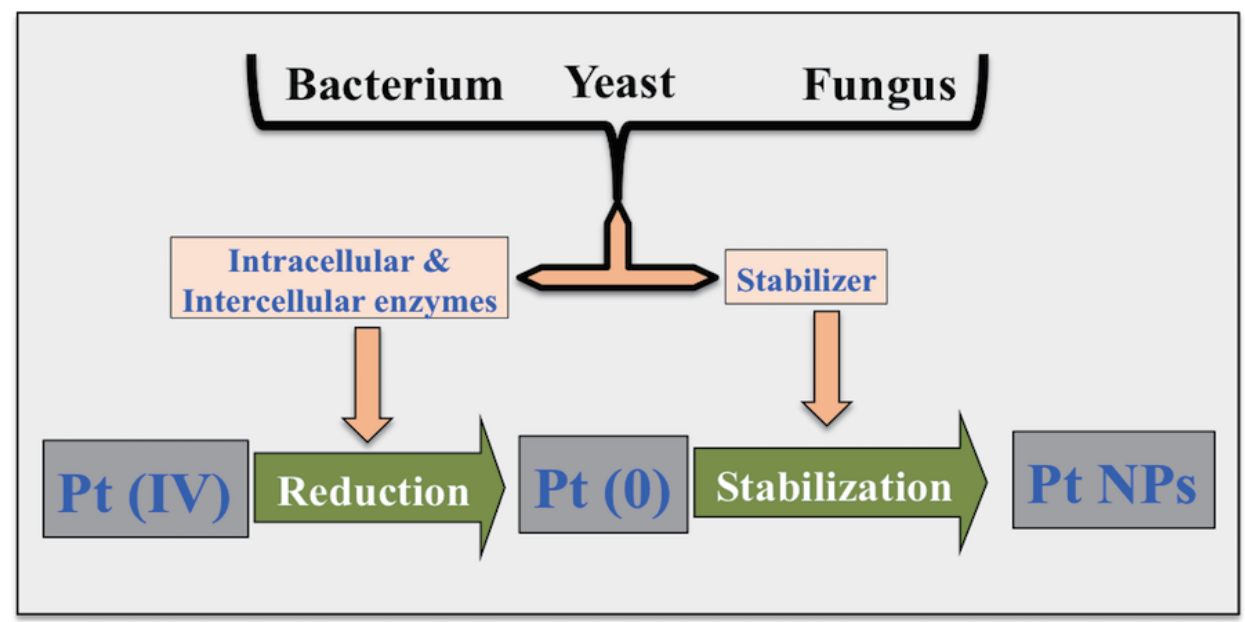

Figure 4. Production of PT NPs by intracellular and extracellular enzymes of bacterial, fungal and yeast cells origin. Enzymes can act as reducing and/or stabilizing agent to synthesize Pt NPs from Pt(IV) precursor ions

Likewise photosynthetic prokaryote, cyanobacteria has also been used for Pt NPs synthesis. Cyanobacteria has been used to treat effluent due to their abilities to uptake metal ions from surrounding. Further being nitrogen fixing microorganism, cyanobacteria produces enzymes that can reduce precursor metal ions to NPs. The ability of cyanobacteria to reduce metal ions is specifically useful to obatin Pt NPs from precursor metal ions. ${ }^{[64]}$ So, depending upon the natural abilities of bacterial strains to uptake metal ion and produce reducing enzymes, the synthesis of Pt NPs can be intra as well as extracellular. Anabaena, Calothrix and Leptolyngbya strain of cyanobacteria have been used for Pt NPs synthesis. The NPs are synthesized intra-cellularly by nitrogenase and released in the culture medium where they are stabilized extracellularly by bacterial polysaccharides. ${ }^{[65]}$
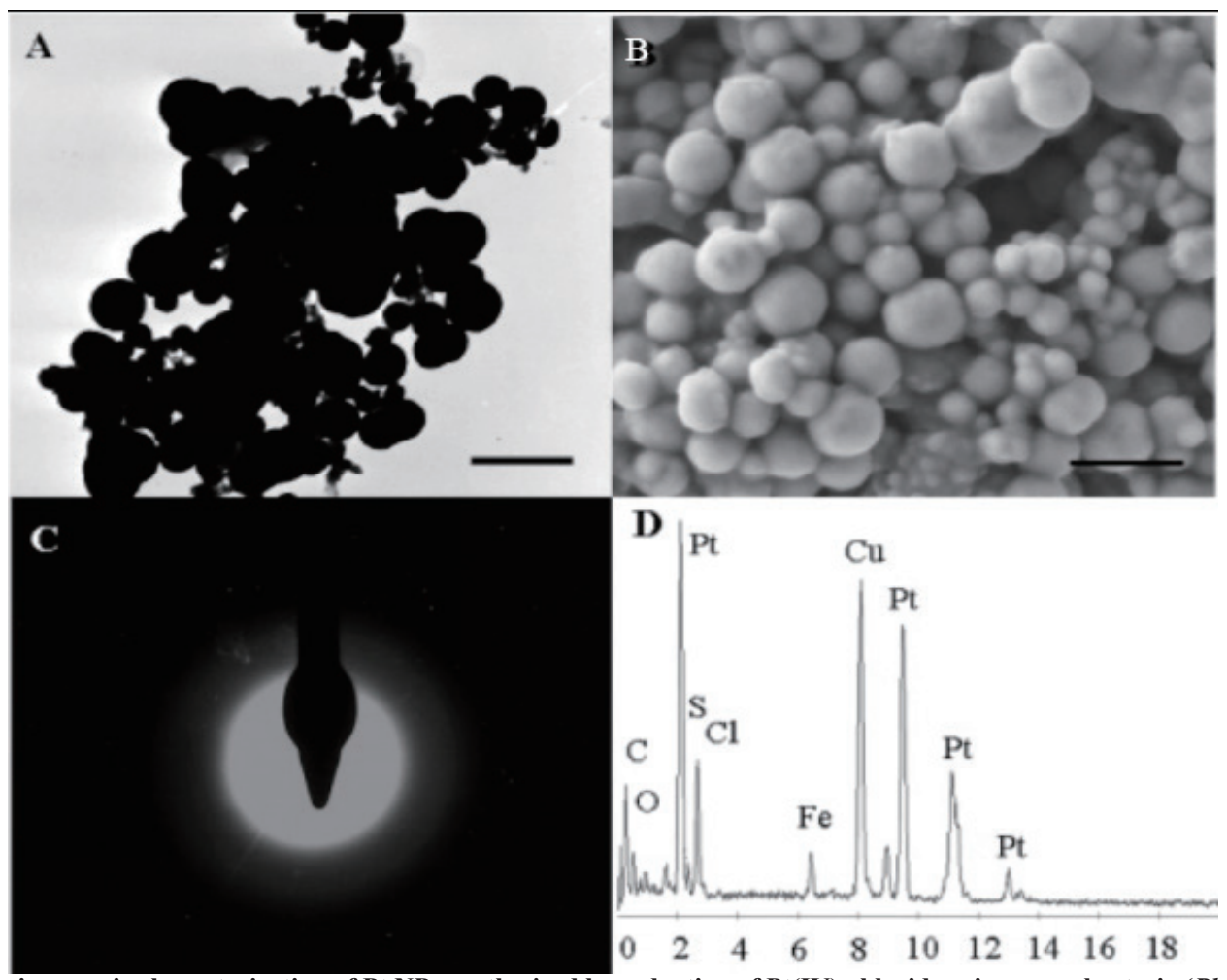

Figure 5. Electron microscopic characterization of Pt NPs synthesized by reduction of Pt(IV)-chloride using cyanobacteria (Plectonema boryanum UTEX 485) at an incubation temperature of $25^{\circ} \mathrm{C}$ and 28 days: (A) TEM image of amorphous spherical Pt NPs; (B) SEM image of spherical Pt NPs; (C) TEM-SAED diffraction of amorphous Pt NPs; (D) TEM-EDS spectrum for panel A (Cu signal is from the supporting grid). Scale bars in panels $A$ and $B$ are $0.5 \mu \mathrm{m}$. "Reprinted with permission from (Lengke et al., 2006) ${ }^{[6]}$. Copyright (2006) American Chemical Society."

\subsubsection{Fungus mediated synthesis}


The physical and chemical methods of metallic reduction facilitating Pt NPs synthesis are comparatively expensive. Hence, use of biological agents is preferred. In addition to bacteria and cyanobacteria mediated NPs synthesis, large scale particle production with the use of fungi has also been reported. Synthesis of Pt NPs by filamentous fungi has more advantage over plant or prokaryotes mediated synthesis approaches. Filamentous fungi can efficiently resist pressure and agitation gradient during the NPs production at industrial scale production. The fungi mediated synthesis is highly stable and prevents molecular agitation. ${ }^{[6]]}$ The filamentous fungi Neurospora crassa has been evaluated as reducing agent for the synthesis of Pt NPss. The fungal wild-strain biomass dispersed in aqueous solution reduced hexachloroplatinic (IV) acid to 40-50 nm Pt NPs. The Pt NPs synthesis was completed within 24 hours, but dark condition and continuous agitation was required ${ }^{[68,69]}$ One pot Pt NPs synthesis has been reported by using the reducing potential of cell free filtrate of fungus Penicillium chrysogenum. The synthesized NPs were spherical and 8.5-15 nm in size. ${ }^{[70]}$ Likewise, $50-315 \mathrm{~nm}$ sized Pt NPs was synthesized using culture filtrate of fungus Alternaria alternate ${ }^{[71]}$ Likewise, hydrogenase enzyme produced by Fusarium oxysporum has been reported for the synthesis of Pt NPs from $\mathrm{H}_{2} \mathrm{PtCl}_{6}$. The synthesis of Pt NPs required prior reduction of $\mathrm{H}_{2} \mathrm{PtCl}_{6}$ to $\mathrm{PtCl}_{2}$ on the enzyme surface such that it was small enough to enter active sites. $\mathrm{PtCl}_{2}$ further underwent reduction process leading to the formation of Pt NPs ${ }^{[72]}$ Protein mediated extracellular synthesis of Pt NPs has been reported using Fusarium oxysporum. Fungus culture could reduce and stabilize Pt NPs produced by reduction of $\mathrm{H}_{2} \mathrm{PtCl}_{6}$. Enzymes were responsible for the reduction and proteins were responsible for the surface stabilization of NPs. ${ }^{[73]}$

\subsubsection{Plant mediated NPs synthesis}

As mentioned earlier, to avoid the use of toxic chemicals during NPs synthesis, greener approaches of synthesis are being formulated and evaluated. Plant mediated NPs synthesis is one of the eco-friendly and green synthesis approach that is fulfilling the principles of green chemistry. Plant extracts has been widely used for the synthesis of metallic NPs. ${ }^{[14]} \mathrm{Pt}$ NPs have also been synthesized by using plant resources. ${ }^{[74,75,76]}$ Being synthesized through greener route, plant extract synthesized NPs are specifically useful for applications that warrant NPs to come in contact with living organisms. Further, use of plant material in synthesis prevents use of harmful chemicals that may otherwise contaminate environment. Plant extract used for NPs synthesis contain various phytochemicals of medicinal importance. Such phytochemicals act to stabilize NPs and may enhance the quality of synthesized NPs. So, synthesis of NPs using medicinally important plant extract is preferred over other biological methods of NPs synthesis. Pt NPs synthesis has already been reported from different plant extracts. ${ }^{[77,78]}$ The plant tuber extract prepared by boiling dry tuber powder of Gloriosa superba has been reported for the Pt NPs synthesis. The tuber extract could reduce precursor $\mathrm{PtCl}_{6}^{2-}$ ions within 5 hours to obtain $0.8-3 \mathrm{~nm}$ spherical Pt NPs. ${ }^{[79]}$ Likewise, leaf extract repaired from traditional medicinal plant Barleria prionitis has been used for the synthesis of 1-2 nm Pt NPs. ${ }^{[78]}$ The studies documenting use of plant extracts for the synthesis Pt NPs is limited as compare to other type of metallic NPs. ${ }^{[14]}$

The synthesis of Pt NPs from the extract of Fumariae herba has been confirmed by UV-visible spectroscopy, Fourier transform infrared spectroscopy, transmission electron microscopy and scanning electron microscopy with EDS profiling. The synthesized NPs were $30 \mathrm{~nm}$ in size and hexagonal and pentagonal in shape ${ }^{[80]}$ Likewise, 100-200 nm small cubic and dodecahedron shaped Pt NPs were synthesized using Jatropha gossypifoliaa and Jatropha glaundulifera leaf extract. ${ }^{[81]}$ Similarly, 1-6 nm sized spherical Pt NPs were synthesized using black cumin (Nigella sativa L) seed extract. ${ }^{[82]}$ 
Table 1. List of plants used for Pt NPs synthesis and their morphological chareatcerstics

\begin{tabular}{|c|c|c|c|c|}
\hline Name of plant & Plant part use & Size (nm) & Shape & Reference \\
\hline Doipyros kaki & Leaf & $2-12$ & ND & [83] \\
\hline Fumariae herba & Whole & 30 & Hexagonal and pentagonal & [81] \\
\hline Piper betle L. & Leaf & $0.4-2$ & Spherical & [84] \\
\hline Ocimum sanctum & Leaf & 23 & Irregular & {$[85]$} \\
\hline Phoenix dactylifera & Fruit & $1.3-2.6$ & Spherical & [86] \\
\hline Lantana camara & Leaf & 35 & Spherical & [87] \\
\hline Prunus yedoensis & Gum & $10-20$ & Circular & [88] \\
\hline Camellia sinensis & Leaf & $30-60$ & Flower & [89] \\
\hline Antigonon leptopus & Whole plant & $5-190$ & Spherical & [90] \\
\hline B. prionitis & Leaf & $1-2$ & Monodispersed & [78] \\
\hline Pinus resinosa & Bark & $6-8$ & Irregular & [91] \\
\hline Gloriosa superb & Tuber & $0.83-3$ & Spherical & [79] \\
\hline Cacumen platycladi & Whole plant & $0.8-2.4$ & Spherical & [92] \\
\hline $\begin{array}{l}\text { Jatropha Gossypifoliaa and } \\
\text { Jatropha Glaundulifera }\end{array}$ & Leaf & $100-200$ & Small cubic and dodecahedron & [81] \\
\hline Nigella sativa $L$. & Seed & $1-6$ & Spherical & [82] \\
\hline Orange & Peel extract & $1.6-4$ & ND & [93] \\
\hline
\end{tabular}

Table 2. Advantages and disadvantages of different methods of Pt NPs synthesis

\begin{tabular}{cccc}
\hline Properties & Chemical synthesis & Physical synthesis & Biological synthesis \\
\hline Productivity & High & Less & High \\
Cost & Low & High & Cost-effective \\
Energy required & High & High & Low \\
Stability & High & How & Low \\
Wastage & High & Low \\
Size and shape tunability & Size controlled & Difficult in size and shape tunability & Definite shape and size \\
Purity & Low & Low & High \\
Chemicals & Uses toxic chemicals & No use of chemicals & No use of chemicals \\
Production & Small scale & Small scale & Large scale
\end{tabular}

\subsection{Application of Pt NPs}

With the advent of nanotechnology, new functional materials are being synthesized. Among which metallic NPs are of particular interest due to their wide range of multidisciplinary applications. The Pt NPs have likewise wide range of physical, chemical and biological applications. The factors responsible for their multi -functionality are their unique physical and chemical properties. ${ }^{[42]}$ Following section describes the various applications of Pt NPs. There are two review that tried to discuss the biomedical application of Pt NPs. ${ }^{[94,95]}$ Although Pt NPs have broader scope and applications in various fields so we discuss various application of Pt NPs in detail (Figure 1).

\subsubsection{Fuel cell catalyst}

\subsubsection{Proton exchange membrane fuel cells}

Proton exchange membrane fuel cells produce electrical energy by chemical reaction at both anode and cathode. The electrochemical reaction between $\mathrm{H}_{2}$ and $\mathrm{O}_{2}$ releases water. On anode, the hydrogen gas adsorbed over catalyst surface loses electron that flow to cathode and proton is released from the metallic surface. With the flow of electrons from anode to cathode, proton is also transported. Oxygen is released at cathode and oxygen accepts the proton and a water molecule is released at the metallic surface. Recently, $\mathrm{Pt}$ is used as a catalyst for the reactions occurring at anode and cathode ${ }^{[96]} \mathrm{Pt}$ NPs are preferred over other metallic membrane fuel cell catalyst due to better catalytic activity, stability and selectivity. Hence, Pt NPs offer an ideal catalyst with enhanced usage and reduced economics. ${ }^{[96]} \mathrm{Pt}$ NPs, $4 \mathrm{~nm}$ functionalized with Ru ions has shown application as an efficient electro-catalyst for proton exchange membrane fuel cells. ${ }^{[96]}$ Multiwalled carbon nanotubes Pt nanocomposites have been synthesized by reducing the Pt atoms on multiwalled carbon nanotubes in ethylene glycol solution. The synthesized NPs showed enhanced electro-catalytic potential when the catalysis of NPs synthesis was conducted in alkaline conditions. ${ }^{[98]}$

\subsubsection{Methanol fuel cell}

Methanol fuel cells are the electrochemical cells generating electricity by oxidation of methanol in the presence of alkaline electrolyte releasing carbon dioxide and water. To eliminate the carbon dioxide emission, $\mathrm{Pt}$ catalysts are used for methanol oxidation in acidic conditions. ${ }^{[99]}$ Further, various strategies of Pt NPs synthesis are being explored 
to ensure their direct usage as electro-catalyst in methanol fuel cells. The synthesis of multi-walled carbon nanotubes supported Pt nanocomposites in ethylene glycol solution showed significantly higher performance as eletcro-catalyst than nanocomposites synthesized in aqueous solution. ${ }^{[100]}$ Likewise, another such study reports an efficient electrocatalytic potential of $\mathrm{Pt}_{52} \mathrm{Ru}_{48} / \mathrm{C}$ nanocolloids than carbon supported Pt of Pt-ruthinium colloids. ${ }^{[101]}$

\subsubsection{Electrochemical oxidation of formic acid}

Electrochemical oxidation of formic acid is of keen interest because of its use in fuel cells and secondly, it acts as model system to study the oxidation of complex organic molecules and formic acid is least reactive and non-explosive. Pt metallic electrode has shown highest efficiency of formic acid oxidation than other metallic electrodes. ${ }^{[102]} \mathrm{Number}$ of Pt based nanomaterials is being synthesized to increase their electro-catalytic activity towards formic acid. Pt NPs layered on gold surface has shown enhanced electro-catalytic activity of formic acid oxidation. ${ }^{[103]}$ Likewise, Pt modified gold NPs showed high electro-catalytic activity than pure Pt NPs. ${ }^{[104]}$

\subsubsection{Catalytic converters}

Pt NPs are used as catalytic converters in car. The exhaust gases from the car react with Pt surface on release as they land on the surface of Pt particles. Pt oxidises the released carbon monoxide and hydrocarbons. Carbon monoxide is toxic in nature and harmful for humans. Breathing of excessive carbon monoxide can leads to death. Pt is more effective under oxygen excessive conditions so it is used in diesel cars. Since Pt has high melting point, it readily interacts with poisonous particles and can be efficiently recycled later. ${ }^{[105]} \mathrm{Pt}$ NPs present on Pt surface of vehicles promotes the chemical reaction occurring on it. They induce the weakening of carbon oxygen bond present in carbon monoxide and oxidize it into carbon dioxide. $^{[106]}$

\subsubsection{Glucose detection application}

$\mathrm{PdCuPt}$ trimetallic nanocrystals has been used as electro-catalysts for enzyme free detection of glucose. Nocrystalline electro-catalysts are easy to fabricate and has high electrocatalytic activity, selectivity and stability. So, the Pt based trimetallic nanocrystals can be used for various medical diagnostic and various other industrial applications. ${ }^{[107]}$ Another study reports the synthesis of glucose enzyme biosensors based on Pt NPs homogenously loaded onto polyaniline hydrogel. These glucose enzyme biosensors showed hydrogel based conductivity and nanoparticle based catalytic potential. Due to the porous structure of the polyaniline hydrogel, the Pt NPs were immobilized and the water soluble molecules penetrated which help in the oxidation of glucose. ${ }^{[108]}$

\subsubsection{Electrochemical sensor for phenol detection}

Phenol and its derivatives are used in many fields. Phenol is ingredient of disinfectants, coating agent, dyes, pharmaceuticals and pesticides. Phenol is also used as vegetables preservative. Phenol and its derivatives also poses some serious ecological threat specifically contaminating the soil surface and ground water. ${ }^{[106]}$ Phenol can enter the human respiratory tract and cause severe health problems particularly in children. So, it is important to develop sensitive, rapid, and economic method for phenol detection. Many analytical methods are used for detection of phenol. For instance, gas chromatography, high-performance capillary zone electrophoresis, high performance liquid chromatography and capillary electrophoresis are used for detection of phenol. These methods are time consuming and expensive. Focus in on the development of electrochemical sensors for phenol detection. Electrochemical sensors show high sensitivity, excellent stability, easy operation and low cost. Pt NPs are widely used in the electrochemical sensors because of their significant catalytic and optical activities. ${ }^{[96]}$ Graphite like carbon nitride is a stable metal free semiconductor material with a smaller visible light driven band gap. ${ }^{[110]}$ It has high sensitivity, good biocompatibility and low cost. Graphite like carbon nitride has wide application in biosensors, degradation of pollutant in water and carbon dioxide reduction. ${ }^{[11]}$ Combination of $\mathrm{Pt}$ and graphite like carbon nitride showed significant electrochemical sensing. Oxidation peak of phenol was indistinct on carbon paper and high peak was observed on the graphite like carbon nitride/carbon paper electrode. Pt NPs when loaded onto the graphite like carbon nitride as $\mathrm{Pt} / \mathrm{g}-\mathrm{C}_{3} \mathrm{~N}_{4} / \mathrm{CP}$ showed highest oxidation peak for significant detection of phenol. ${ }^{[111]}$

\subsubsection{Biological applications}

Pt NPs have various biological applications because of its unique electronic and physiochemical properties. They have emerged as the most potential functional biomaterials to possess application in drug delivery, diagnostics and imaging. ${ }^{[12]}$ Following sections describes the potent biological applications of Pt NPs.

\subsubsection{Cancer therapy}

\subsection{Chemical cancer treatment}

Pt has been used in cancer treatment as most available cancer drugs are Pt based. Work is being in progress to develop next generation of Pt drugs with modified nanoformulations. ${ }^{[113]}$ The spherical shaped bacitracin-Pt NPs (Bac-PtNPs) have 
been developed to possess significant in vivo and in vitro anti- tumorous activity. The spherical shaped Bac-PtNPs were aqueous stable and cubic crystalline in shape. The presence of functional groups on bacitracin acted as binding moieties that supported the growth of Pt NPs. ${ }^{[114]} \mathrm{TiO}_{2}$ and $\mathrm{SiO}_{2}$ nanostructures containing 3-4\% of Pt have shown anti-cancerous activity and used for the cancer treatment. Treatment with these nanostructures induced significant reduction in size and weight of rat weight tumor. ${ }^{[15]}$ In brain cancer therapy, Pt NPs have also shown ability to activate cellular apoptosis in tumors together with the ability to cross the blood barrier. ${ }^{[116]}$

\subsection{Photothermal therapy and radiotherapy}

Due to the toxic side effects of anticancer chemotherapies, more effective and site specific strategy is developed for treatment of malignant tumors. The photothermal therapy is non-invasive due to the use of Pt NPs. In this treatment, Pt NPs increased the cellular temperature upon irradiation causing DNA/RNA damage, membrane rupture, protein denaturation and finally apoptosis. ${ }^{[117]}$ Researches mostly used carbon nanotubes, graphene NPs, copper sulphide and noble NPs for cancer treatment. These nanomaterials are capable for absorbing NIR laser light and evaporate it into heat. The photothermal therapy has been improved by combining the cyto-compatibility and catalytic properties of Pt NPs. ${ }^{[18]}$. The recommended size of Pt NPs for photothermal therapy is 5-6 nm. Pt NPs are good material for the photothermal therapy and radiotherapy as they damage the cellular component of the selective area and induce cell death. ${ }^{[18]}$

\subsubsection{Antibacterial agent}

The existence of multi drug resistance bacteria is the greatest threat and challenge in the development of antibacterial agents. NPs composed of metals like $\mathrm{Ag}, \mathrm{Pd}, \mathrm{Au}, \mathrm{Cu}, \mathrm{ZnO}$ and $\mathrm{TiO}_{2}$ are generally used for the development of bactericidal agents. However, side-effects associated with the use of these NPs have limited their therapeutic applications. ${ }^{[119]} \mathrm{Pt}$ ions have been considered to possess potent antimicrobial activity on E. coli. However, the antibacterial potential of Pt NPs is still not well understood. Pt NPs has been reported to induce intracellular ATP hyper production, growth inhibition and DNA damage generating a significant bacteriotoxic response ${ }^{[120]}$ Enhanced ATP production on Pt NPs exposure increases the expression of kinase that is responsible for cellular growth arrest. ${ }^{[121]}$ Small sized Pt NPs have shown significant bacteriotoxic property at low concentration. TEM analysis revealed that size played an important role as larger sized NPs absorbed onto the plasma membrane whereas smaller sized NPs easily invaded the bacterial cells. ${ }^{[122]} \mathrm{Pt}$ NPs have also shown activity against gram negative and gram positive bacteria. Pt ions can invade the peptidoglycan composed cell wall of gram negative bacteria. ${ }^{[123]} \mathrm{Pt}$ NPs has potential even to cure drug resistant E. coli. ${ }^{[124]}$

\subsubsection{Nanomedicine}

Pt NPs are antioxidant in nature that has the ability to scavenge reactive oxygen species. They are good source as nanozymes for the treatment of oxidative stress related diseases. Pt NPs have been functionalized by saponins to develop saponins-Pt conjugates that showed significant antioxidant activity. The conjugates regulated macrophage inflammatory protein-2 (MIP-2) gene expression and inhibited the mitogen-activated protein (MAP) kinase pathway ${ }^{[125]} \mathrm{Pt}$ NPs have been reported to prevent cancer and cardiovascular diseases as they possess in vitro enzyme like property. Pt NPs have good stability in acidic cellular vesicle environments leading to high in vivo tolerance. ${ }^{[20]}$

Pt NPs have shown ability to shield the cell from reactive oxygen species that can induce cell death on exposure to UV-A or X-Ray or ultrasound radiations. ${ }^{[126,127]} \mathrm{Pt}$ NPs are defined to possess horseradish peroxide and catalase mimetic enzyme activities when embedded in the dendrimers. ${ }^{[128]} \mathrm{Pt}$ NPs have ability to quench the peroxide and superoxide ions both in cell free solution and within cell when encapsulated with-in the cavity of apoferitin. It can also increase the antioxidant property. ${ }^{[129]}$

\subsubsection{Nanodignosis}

Pt NPs are also significantly used for disease diagnostics. Fluorscent Pt NPs are used in biocompatible bioimaging probe for diagnostic purposes. ${ }^{[130]} \mathrm{Pt}$ nanomaterials is a part of catalytic nanomotors that are used to built-up the molecular devices and detect motion based particles. ${ }^{[112]} \mathrm{Pt}$ NPs are also good source of enzyme alternates used for diagnostic purpose. ${ }^{[131]} \mathrm{Pt}$ NPs have so many advantages including stability, resistance to proteases, high catalytic activity even at high $\mathrm{pH}$ and temperature, and affinity for horseradish peroxidase (HRP) substrates. ${ }^{[132]}$

Pt NPs colorimetric assay have been develop ${ }^{[132]}$ for the detection of $\mathrm{DNA}^{[133]}$, cancer cells ${ }^{[21]}$, tumor marker ${ }^{[17]}$, metal ions ${ }^{[134]}$, penicillin antibiotics ${ }^{[135]}$, drugs ${ }^{[11]}$, hydrogen peroxide ${ }^{[28]}$, glucose ${ }^{[136]}$, cholestro ${ }^{[137]}$, L-cysteine ${ }^{[138]}$, choline, acetylcholine ${ }^{[139]}$, proteins ${ }^{[140]}$, viruses ${ }^{[141]}$, bacteria ${ }^{[142]}$ and antibodies ${ }^{[143]}$. Irregular shape of Pt NPs act as HRP like enzymes when these binds with the anti-RigG antibody which is used in the Enzyme Linked Immunosorbent Assay for the colorimetric detection of rabbit IgG, using $3,3^{\prime}, 5,5^{\prime}$ - tetramethylbenzidine (TMB) and hydrogen peroxide $\left(\mathrm{H}_{2} \mathrm{O}_{2}\right)$ as substrates. ${ }^{[143]}$ Encapsulated Pt NPs in mesoporous silica matrix are used for the detection of level free DNA. ${ }^{[144]}$ TMB oxidation catalyzed by 4-mercaptophenylboronic acid functionalized Au@Pt NPs are used for the highly sensitive assay 
for the detection of E. coli. Pt NPs based sensors has also been used for the detection of mercury in the environment. ${ }^{[145]}$

Table 3. Application of Pt NPs in different area

\begin{tabular}{|c|c|c|}
\hline Application & Exact role/mode of action & Reference \\
\hline $\begin{array}{l}\text { Proton exchange membrane } \\
\text { fuel cell }\end{array}$ & Pt use as a catalyst for reaction occurring at anode and cathode & {$[96],[146]$} \\
\hline Methanol fuel cell & Pt catalysts are used for methanol oxidation in acidic conditions. & [99], [147] \\
\hline $\begin{array}{l}\text { Electrochemical oxidation of } \\
\text { formic acid }\end{array}$ & $\begin{array}{l}\text { Pt metallic electrode has shown highest efficiency of formic acid oxidation and Pt NPs } \\
\text { layered on gold surface has shown enhanced electro-catalytic activity of formic acid } \\
\text { oxidation }\end{array}$ & {$[102],[103]$} \\
\hline Glucose detection & $\begin{array}{l}\text { PdCuPt nanocrystals used as non enzymetic detection of glucose. Can be used for } \\
\text { disease diagnosis, quality check in beverage industries, in bioprocess monitoring and in } \\
\text { environment monitoring. }\end{array}$ & {$[105]$} \\
\hline Catalytic converters & $\begin{array}{l}\text { Pt NPs are used as catalytic converters in car. Pt NPs present on Pt surface of vehicles } \\
\text { promotes the chemical reaction occurring on it and weaken the carbon oxygen bond } \\
\text { present in carbon monoxide and oxidize it into carbon dioxide. }\end{array}$ & {$[105]$} \\
\hline $\begin{array}{l}\text { Electrochemical sensor for } \\
\text { phenol detection }\end{array}$ & $\begin{array}{l}\text { Pt NPs are used for electrochemical sensing of phenols because of their significant } \\
\text { catalytic and optical activities. }\end{array}$ & [96] \\
\hline Supercapacitors & $\begin{array}{c}\text { Pt NPs decorated with Graphene- polyaniline form modified electrode for supercapacitor } \\
\text { application }\end{array}$ & [148] \\
\hline Oxygen reduction reaction & Pt NPs based on carbon quantum dots are used in the oxygen reduction reaction & [149] \\
\hline Xanthine sensor & $\begin{array}{l}\text { Pt NPs is synthesised by loaded on the metal organic framework of type MIL- } 101 \text {. } \\
\text { This xanthine sensor is used for the detection of dopamine, uric acid, xanthine and } \\
\text { hypoxanthine. }\end{array}$ & {$[150]$} \\
\hline Cancer treatment & Pt NPs for anti-cancerous activity & [115] \\
\hline MCF-7 breast cancer cells & Pt NPs synthesised from Streptomyces sp.is used for the treatment of breast cancer. & [151] \\
\hline Photothermal and raidotherapy & $\begin{array}{l}\text { Pt NPs increased the cellular temperature upon irradiation causing DNA/RNA damage, } \\
\text { membrane rupture, protein denaturation and finally apoptosis }\end{array}$ & [117] \\
\hline Bioimaging & Fluorscent Pt NPs are used in biocompatible bioimaging probe for diagnostic purposes. & [130] \\
\hline Drug delivery & $\begin{array}{c}\text { Pt NPs are used as a vector for delivery of anti-tumors drugs in the cancer treatment and } \\
\text { chemotherapy }\end{array}$ & [152], [153] \\
\hline Antibacterial and antifungal & $\begin{array}{l}\text { Pt NPs has been reported to induce intracellular ATP hyper production, growth inhibition } \\
\text { and DNA damage generating a significant bacteriotoxic response. Pt ions can invade the } \\
\text { peptidoglycan composed cell wall of gram negative bacteria }\end{array}$ & [120], [123] \\
\hline Nano- medicine & Pt NPs counter oxidative stress & {$[126],[127]$} \\
\hline Nano-diagnostics & Pt NPs are used in many colorimetric assay & {$[11],[17],[21],[28],[133-143]$} \\
\hline
\end{tabular}

\section{Cytotoxic effect of Pt NPs}

Pt NPs has been found to induce cytotoxic response to various cancerous cells. Exposure of $50-200 \mathrm{~g} / \mathrm{ml}$ of Pt NPs for 48 hours has been documented to induce cytotoxicity to A549, PA-1 and Mia-Pa-Ca-2 cancerous cell lines. MTT assay was used for the determination of cell viability. Pt NPs reduced the growth of cancerous cell by 28-34 in A549, 33-46\% in PA-1 and 11-41\% in Mia-Pa-Ca-2 cells. However, PA-1 cells showed highest growth inhibitory effect of Pt NPs. Apoptosis, autophagy and necrosis are the three major types of cell death. PA- 1 cells treated with $200 \mathrm{~g} / \mathrm{ml}$ of Pt NPs for 48 hours showed enhanced apoptosis. ${ }^{[154],[155]}$ Likewise, treatment of murine leukemia raw 264.7 cells with different concentrations of Pt NPs induced cytotoxicity. Cell morphology evaluation, Annexin V assay, DNA fragmentation and the activity analysis of caspase-3/7 showed promoted apoptosis in the Raw 264.7 cells. The ill effects were due to change in cell morphology, increase in cell density and nucleus fragmentation. Caspase-3 and caspase-7 was found to induce apoptosis in the cells. Pt NPs inactivated the DNA repair system of cells. ${ }^{[156]}$ Exposure of HEK293 cells to 20-360g/ml of Pt NPs for 6, 24 and 48 hours revealed toxic response of Pt NPs. Cell viability was found to be $99.06 \%, 96.9 \%, 98.5 \%$ and $88.5 \%$ after 6 hours, $95 \%, 91 \%, 83 \%$, and 70\% after 24 hours; and 90\%, 86\%, 68.25\%, and 54.15\% after 48 hours of Pt NPs exposure. The Pt NPs induced cytotoxicity was reported to be time dependent. ${ }^{[157]}$ Overall Pt NPs may induce toxic response to cancerous cell lines. However, the exact toxicity behaviour of Pt NPs of different sizes needs to be tested using more realstic in vivo studies.

\section{Conclusion and outlook}

The synthesis of Pt NPs can be manipulated to produce NPs of different sizes and shapes. The varying size and shape imparts different physical, chemical and biological properties to the Pt NPs. Stable Pt NPs obtained through greener biological route are suitable for various biological applications. Such greener Pt NPs are significantly useful in cancer diagnosis, photothermal and antibacterial therapy. Pt NPs has the potential of even replacing the conventional drugs for cancer treatment. The Pt NPs are of importance even for some of the non-biological applications like catalysis, 
nanodiagnosis and development of durable proton exchange membrane fuel cell. Pt NPs being composed of noble metal chemical composition has potential applications because of stable and least reactive surface coating material. Overall, $\mathrm{Pt}$ NPs have wide range of biological and non-biological industrial applications. In vitro cytotoxicity studies conducted using cell lines indicate toxic behaviour of Pt NPs towards cancerous cells. In depth in vitro and in vivo toxicity experimentation proving safety of Pt NPs can help in exploring their new applications in therapeutics and diagnosis.

\section{References}

[1] Ogino C, Kanehira K, Sasai R, Sonezaki S, Shimizu N. Recognition and effective degradation of 17 [beta]-estradiol by anti-estradiol-antibody-immobilized $\mathrm{TiO}_{2}$ nanoparticles. J Biosci Bio Eng. 2007; 104: 339-342.

[2] Oberdorster G, Maynard A, Donaldson K. Principles for characterizing the potential human health effects from exposure to nanomaterials: elements of a screening strategy. Particle Fibre Toxicol. 2005; 2: 1-8.

[3] Borm P, Robbins D, Haubold S, Kuhlbusch T, Fissan H, Donaldson K, Schins R, Stone V, Kreyling W, Lademann J, Krutmann J, Warheit D, Oberdorster E. The potential risks of nanomaterials: a review carried out for ECETOC. Particle, Fibre Toxicol. 2006; 3(1): 11.

[4] Kreyling W, Semmler-Behnke M, Muller W. Health implications of nanoparticles. J. Nanopart. Res. 2006; 8: 543562.

[5] Lam CW, James JT, McCluskey R, Arepalli S, Hunter RL. A review of carbon nanotube toxicity and assessment of potential occupational and environmental health risks. Crit. Rev. Toxicol. 2006; 36: 189-217.

[6] Maynard AD. Nanotechnology: The next big thing, or much ado about nothing? Ann. Occup. Hyg. 2007; 51: 1-12.

[7] Bruchez M, Moronne M, Gin P, Weiss S, Alivisatos AP. Semiconductor nanocrystals as fluorescent biological labels. Science 1998; 281: 2013-2016.

[8] Mah C., Zolotukhin I, Fraites TJ, Dobson J, Batich C, Byrne BJ. Microsphere-mediated delivery of recombinant AAV vectors in vitro and in vivo. Mol Therapy. 2000; 1 : S239.

[9] Edelstein RL, Tamanaha CR, Sheehan PE, Miller MM, Baselt DR, Whitman LJ, Colton RJ. The BARC biosensor applied to the detection of biological warfare agents. Biosensors Bioelectron. 2000; 14: 805-813.

[10] Parak WJ, Boudreau R, Gros ML, Gerion D, Zanchet D, Micheel CM, Williams SC, Alivisatos AP, Larabell C. Cell motility and metastatic potential studies based on quantum dot imaging of phagokinetic tracks. Adv Mater. 2002; 14: $882-885$

[11] Sharma N, Ojha H, Bharadwaj A, Pathak DP, Sharma RK. Preparation and catalytic applications of nanomaterials: a review. RSC Adv. 2015; 5: 53381-53403.

[12] Li T, Liu J, Song Y, Wang F. Photochemical solid-phase synthesis of platinum single atoms on nitrogen-doped carbon with high loading as bifunctional catalysts for hydrogen evolution and oxygen reduction reactions. ACS Catal. 2018; 8(9): 8450-8458.

[13] Xiang ZP, Deng HQ, Peljo P, Fu ZY, Wang SL, Mandler D, Sun GQ, Liang ZX. Electrochemical dynamics of a single platinum nanoparticle collision event for the hydrogen evolution reaction. Angew. Chem. Int. Ed. 2018; 57: 34643468.

[14] Kumar V, Yadav SK. Plant-mediated synthesis of silver and gold nanoparticles and their applications. J. Chem. Technol. Biotechnol. 2009; 84: 151-157.

[15] Kumar V, Jain A, Wadhawan S, Mehta SK. Synthesis of biosurfactant-coated magnesium oxide nanoparticles for methylene blue removal and selective Pb2+ sensing. IET Nanobiotechnol. 2017; 12(3): 241-253.

[16] Shao-Horn Y, Sheng WC, Chen S, Ferreira PJ, Holby EF, Morgan D. Instability of supported platinum nanoparticles in low-temperature fuel cells. Topics in Catalysis. 2007; 46(3-4): 285-305.

[17] Choi G, Kim E, Park E, Lee JH. A cost-effective chemiluminescent biosensor capable of early diagnosing cancer using a combination of magnetic beads and platinum nanoparticles. Talanta. 2017; 162: 38-45.

[18] Cheng H, Xi C, Meng X, Hao Y, Yu Yand Zhao F. Polyethylene glycolstabilized platinum nanoparticles: The efficient and recyclable catalysts for selective hydrogenation of o-chloronitrobenzene to o-chloroaniline. J. Colloid Interface Sci. 2009; 336: 675-678.

[19] Hall MD, Mellor HR, Callaghan R, Hambley TW. Basis for design and development of platinum (IV) anticancer complexes. J. Med. Chem. 2007; 50: 3403-3411.

[20] Hosaka H, Haruki R, Yamada K, Böttcher C, Komatsu T. 2014. Hemoglobin - albumin cluster incorporating a Pt nanoparticle: Artificial $\mathrm{O}_{2}$ carrier with antioxidant activities. PLoS One. 2014; 9: e110541.

[21] Zhang LN, Deng HH, Lin FL, Xu XW, Weng SH, Liu AL, Lin XH, Xia XH and Chen W. In situ growth of porous platinum nanoparticles on graphene oxide for colorimetric detection of cancer cells. Anal. Chem. 2014; 86: 27112718 . 
[22] Handy R, Shaw B. Toxic effects of nanoparticles and nanomaterials: Implications for public health, risk assessment and the public perception of nanotechnology. Health Risk Soc. 2007; 9: 125-144.

[23] Liu H, Li C, Ren X. Fine platinum nanoparticles supported on a porous ceramic membrane as efficient catalysts for the removal of benzene. Sci. Rep. 2017; 7: 16589.

[24] Chehrghani A, Torkamany MJ. Nonlinear optical properties of laser synthesized Pt nanoparticles: saturable and reverse saturable absorption. Laser Phys. 2014; 24: 015901.

[25] Prasetya OD, Khumaeni A. Synthesis of colloidal platinum nanoparticles using pulse laser ablation method. International Conference on Science and Applied Science (ICSAS). AIP Conf. Proc. 2018; 020050-1-020050-3: https://doi.org/10.1063/1.5054454.

[26] Nguyen TB, Nguyen TD, Nguyen, QD, Nguyen TT. Preparation of platinum nanoparticles in liquids by laser ablation method. Adv. Nat. Sci. Nanosci. Nanotechnol. 2014; 5: 035011.

[27] Dobrzanski LA, Szindler M, Pawlyta M, Szindler MM, Borylo P, Tomiczek B. Synthesis of Pt nanowires with the participation of physical vapour deposition. Open Phys. 2016; 14: 159-165.

[28] Hu X, Saran A, Hou S, Wen T, Ji Y, Liu W, Zhang H, He W, Yin JJ, Wu X. Au@ PtAg core/shell nanorods: tailoring enzyme-like activities via alloying. RSC Adv. 2013; 3: 6095-6105.

[29] Deng L, Nguyen MT, Yonezawa T. Sub-2 nm single-crystal Pt nanoparticles via sputtering onto a liquid polymer. Langmuir. 2018; 348: 2876-2881.

[30] Velasco V, Martinez A, Recio J, Hernando A, Crespo, P. Synthesis and characterization of FePt nanoparticles by high energy ball milling with and without surfactant. J. Alloy. Comp. 2012; 536: 13-16.

[31] Zhou, M, Zhao J, Zhang P, Chenc N, Yang S. Solvent-free and rapid synthesis of mesoporous Pt-iron oxide catalysts via mechanochemical assembly. Catal. Sci. Technol. 2019; 9: 3907-3913.

[32] Park KW, Choi JH, Kwon BK, Lee SA, Sung YE. Chemical and electronic effects of Ni in Pt/Ni and Pt/Ru/Ni alloy nanoparticles in methanol electrooxidation. J. Phys. Chem. B. 2002; 106: 1869.

[33] Jiang J and Kucernak A. Electrooxidation of small organic molecules on mesoporous precious metal catalysts: II: CO and methanol on platinum-ruthenium alloy. J. Electroanal. Chem. 2003; 543: 187-199.

[34] Belapurkar AD, Kapoor S, Kulshreshtha SK, Mittal JP. Radiolytic preparation and catalytic properties of platinum nanoparticles, Mater. Res. Bull. 2001; 36: 145-151.

[35] Chen W, Zhang J, Cai W. Sonochemical preparation of Au, Ag, $\mathrm{Pd} / \mathrm{SiO}_{2}$ mesoporous nanocomposites, Scr. Mater. 2003; 48: 1061-1066.

[36] Yang J, Lee JY, Deivaraj TC, Too HP. An improved procedure for preparing smaller and nearly monodispersed thiolstabilized platinum nanoparticles. Langmuir 2003; 19(24 ):10361-10365.

[37] Nie L, Meng, A, Yu J, Jaroniec M. Hierarchically macro-mesoporous $\mathrm{Pt} / \mathrm{c}-\mathrm{Al}_{2} \mathrm{O}_{3}$ composite microspheres for efficient formaldehyde oxidation at room temperature. Sci. Rep. 2013; 3: 3215.

[38] Li J, Yan F, Mo S, Liu H, Chen Y, Yang J. Nanodendritic platinum supported on $\gamma$-alumina for complete benzene oxidation. Part. Part. Syst. Char. 2016; 33(9): 620-627.

[39] Machino T, Takeuchi W, Kano H, Hiramatsu M, Hori M. Synthesis of platinum nanoparticles on two-dimensional carbon nanostructures with an ultrahigh aspect ratio employing supercritical fluid chemical vapor deposition process. Appl. Phys. Exp. 2009; 2(2): 025001.

[40] Hiramatsu M, Hori M. Preparation of dispersed platinum nanoparticles on a carbon nanostructured surface using supercritical fluid chemical deposition. Materials (Basel). 2010; 3: 1559-1572.

[41] Roy A, Bhattacharya J. A binary and ternary adsorption study of wastewater Cd (II), Ni (II) and Co (II) by $\gamma$-Fe $\mathrm{O}_{3}$ nanotubes. Sep. Purif. Technol. 2013; 115: 172-179.

[42] Stepanov AL, Golubev AN, Nikitin SI, Osin YN. A Review on the fabrication and properties of platinum nanoparticles. Rev. Adv. Mater Sci. 2014; 38: 160-175.

[43] Luty-Blocho M, Wojnicki M, Paclawski K, Fitzner K. The synthesis of platinum nanoparticles and their deposition on the active carbon fibers in one microreactor cycle. Chem. Eng. J. 2013; 226: 46-51.

[44] Luty-Blocho M, Wojnicki M, Grzonka J, Kurzydłowski KJ. The synthesis of stable platinum nanoparticles in the microreactor. Arc. Metal. Mat. 2014; 59(2): 509-512.

[45] Wojnicki M, Kwolek P. Reduction of hexachloroplatinate(IV) ions with methanol under UV radiation. J. Photochem. Photobiol. 2016; 314: 133-142.

[46] Bai L, Zhu H, Thrasher JS, Street SC. Synthesis and electrocatalytic activity of photoreduced platinum nanoparticles in a poly(ethylenimine) matrix. ACS App. Mater. Interface. 2009; 1(10): 2304-2311.

[47] Gharibshahia E, Saion E, Ashraf A, Gharibshahia L. Size-controlled and optical properties of platinum nanoparticles by gamma radiolytic synthesis. Appl. Rad. Isotop. 2017; 130: 211-217.

[48] Wang J, Li B, Yersak T, Yang D, Xiao Q, Zhang J, Zhang. Recent advances in Pt-based octahedral nanocrystals as high performance fuel cell catalysts. J. Mat. Chem. 2016; 4(30): 11559-11581. 
[49] Long NV, Chien ND, Hayakawa T, Hirata H, Lakshminarayana G, Nogami M. The synthesis and characterization of platinum nanoparticles: a method of controlling the size and morphology. Nanotechnology. 2010; 21(3): 035605.

[50] Li C, Sato T, Yamauchi Y. Electrochemical synthesis of one-dimensional mesoporous Pt nanorods using the assembly of surfactant micelles in confined space. Angew. Chem. Int. Ed. 2013; 52(31): 8050-8053.

[51] Ahmadi TS, Wang ZL, Green TC, Henglein A, El-Sayed MA. Shape-controlled synthesis of colloidal platinum nanoparticles. Science 1996: 272(5270): 1924-1926.

[52] Yoo JW, Lee SM, Kim HT. Shape control of platinum nanoparticles by using different capping organic materials. Bull. Korean Chem. Soc. 2004; 25(3): 395-396.

[53] Loukrakpam, R, Chang P, Luo J, Fang B, Mott D, Bae IT, Naslund HR, Engelhard MH, Zhong CJ. Chromiumassisted synthesis of platinum nanocube electrocatalysts. Chem. Comm. 2010; 46: 7184-7186.

[54] Zhang L, Li N, Gao F, Hou L, Xu Z. Insulin amyloid fibrils: an excellent platform for controlled synthesis of ultrathin superlong platinum nanowires with high electrocatalytic activity. J. Am. Chem. Soc. 2012; 134: 11326-11329.

[55] Yang M, Cai Q, Liu Z, Wu R, Sun D, Chen Y, Tang Y, Lu T. Monodispersed hollow platinum nanospheres: facile synthesis and their enhanced electrocatalysis for methanol oxidation. J. Mat. Chem. 2014; 2: 13738-13743.

[56] Torres E, Ranasinghe RJ, Alocilja EC. Characterization and functionalization of biogenic gold nanoparticles for biosensing enhancement. IEEE Trans. Nanotechnol. 2010; 9(5): 533-538.

[57] Assuncao A, Matos A, da Costa AMR, Candeias A, Costa MC. A bridge between liquid-liquid extraction and the use of bacterial communities for palladium and platinum recovery as nanosized metal sulphides. Hydrometallurgy. 2016; 163: 40-48.

[58] Thondavada N, Chokkareddy R, Redhi GG. Green synthesis of platinum nanoparticles and their biomedical applications. Green Metal Nanoparticles: Synthesis, Characterization and Their Applications. 2018; 22: 603-27.

[59] Rashamuse, KJ, Whiteley CG. Bioreduction of Pt (IV) from aqueous solution using sulphate-reducing bacteria. Appl. Microbio. Biotechnol. 2007; 75(6): 1429-1435.

[60] White C, Gadd GM. Mixed sulphate-reducing bacterial cultures for bioprecipitation of toxic metals: factorial and response-surface analysis of the effects of dilution rate, sulphate and substrate concentration. Microbiology 1996; 142(8): 2197-2205.

[61] Riddin T, Gericke M, Whiteley, CG. Biological synthesis of platinum nanoparticles: effect of initial metal concentration. Enzy. Micro. Tech. 2010; 46(6): 501-505.

[62] Baskaran B, Muthukumarasamy A, Chidambaram S, Sugumaran A, Ramachandran K, Manimuthu TR. Cytotoxic potentials of biologically fabricated platinum nanoparticles from Streptomyces sp. on MCF-7 breast cancer cells. IET Nanobiotechnol. 2016; 11: 241-246.

[63] Gaidhani SV, Yeshvekar RK, Shedbalkar UU. Bio-reduction of hexachloroplatinic acid to platinum nanoparticles employing Acinetobacter calcoaceticus. Process Biochem. 2014; 49(12): 2313-2319.

[64] Prakasham RS, Ramakrishna SV. The role of cyanobacteria in effiuent treatment. J. Sci. Indust. Res. 1998; 57(5): 258265.

[65] Brayner R, Barberousse H, Hemadi M, Djedjat C, Yepremian C, Coradin T, Livage J, Fiévet F, Coute A. Cyanobacteria as bioreactors for the synthesis of $\mathrm{Au}, \mathrm{Ag}, \mathrm{Pd}$, and $\mathrm{Pt}$ nanoparticles via an enzyme-mediated route. $J$. Nanosci. Nanotechnol. 2007; 7: 2696-2708.

[66] Lengke MF, Fleet ME, Southam G. Synthesis of platinum nanoparticles by reaction of filamentous cyanobacteria with platinum (IV)-chloride complex. Langmuir. 2006; 22(17): 7318-23.

[67] Narayanan KB, Sakthivel N. Biological synthesis of metal nanoparticles by microbes. Adv. Colloid Interface Sci. 2010; 156: 1-13.

[68] Konishi Y, Ohno K, Saitoh N, Nomura T, Nagamine S, Hishida H, Takahashi Y, Uruga T. Bioreductive depostion of platinum nanoparticles on bacterium. Shewanella algae. J. Biotechnol. 2006; 128: 1129-1132.

[69] Castro-Longoria E, Moreno-Velasquez SD, Vilchis-Nestor AR, Arenas-Berumen E, Avalos-Borja E. Production of platinum nanoparticle and nanoaggregates using Neurospora crassa. J. Micro. Biotechnol. 2012; 22: 1000-1004.

[70] Subramaniyan SA, Sheet S, Vinothkannan M., Yoo DJ, Lee YS, Belal SA, Shim KS. One-pot facile synthesis of Pt nanoparticles using cultural filtrate of microgravity simulated grown P. chrysogenum and their activity on bacteria and cancer cells. J Nanosci. Nanotechnol. 2018; 18: 3110-3125.

[71] Sarkar J, Acharya K. Alternaria alternata culture filtrate mediated bioreduction of chloroplatinate to platinum nanoparticles. Inorg. Nano-Metal Chem. 2016; 47: 365-369.

[72] Govender Y, Riddin T, Gericke M, Whiteley CG. Bioreduction of platinum salts into nanoparticles: a mechanistic perspective. Biotechnol. Letts. 2009; 31(1): 95-100.

[73] Syed A, Ahmad A. Extracellular biosynthesis of platinum nanoparticles using the fungus Fusarium oxysporum. Colloid. Surface. 2012; 97: 27-31.

[74] Mittal AK, Chisti Y., Banerjee UC. Synthesis of metallic nanoparticles using plant extracts Biotechnol. Adv. 2013; 31: 
346-356.

[75] Makarov VV, Love AJ, Sinitsyna OV, Makarova SS, Yaminsky IV, Taliansky ME, Kalinina NO. Green nanotechnologies: Synthesis of metal nanoparticles using plants. Actanaturae. 2014; 6: 35.

[76] Jyoti K, Baunthiyal M, Singh A. Characterization of silver nanoparticles using Urtica dioica Linn. Leaves and their synergistic effects with antibiotics. J. Rad. Res. Appl. Sci. 2016; 9: 217-227.

[77] Thirumurugan A, Aswitha P, Kiruthika C, Nagarajan S, Christy AN. Green Synthesis of platinum nanoparticles using Quercus glauca extract and its electrochemical oxidation of hydrazine in water samples. Mater. Lett. 2016; $170: 175$.

[78] Rokade SS, Joshi KA, Mahajan K. Novel anticancer platinum and pladinum nanoparticels from Barleria prionitis. Global J. Nanomed. 2017; 2: 555600.

[79] Thirumurugan A, Aswitha P, Kiruthika C, Nagarajan S, Nancy CA. Green synthesis of platinum nanoparticles using Azadirachta indica- an eco-friendly approach. Mater Lett. 2016; 170: 175-178.

[80] Dobrucka R. Biofabrication of platinum nanoparticles using Fumariae herba extract and their catalytic properties. Saudi J. Biol. Sci. 2019; 26: 31-37.

[81] Jeyapaul U, Kala MJ, Bosco AJ, Piruthiviraj P, Easuraja M. An Eco-friendly Approach for Synthesis of Platinum Nanoparticles using Leaf Extracts of Jatropa Gossypifolia and Jatropa Glandulifera and its Antibacterial Activity. Orient. J. Chem. 2018; 34: 783-790.

[82] Aygun A, Gülbagca F, Ozer LY, Ustaoglu B, Altunoglu YC, Baloglu MC, Sen F. Biogenic platinum nanoparticles using black cumin seed and their potential usage as antimicrobial and anticancer agent. J. Pharmaceut. Biomed. 2020; 179: 112961.

[83] Song JY, Kwon EY, Kim BS. Biological synthesis of platinum nanoparticles using Diopyros kaki leaf extract. Bioproc. Biosyst. Eng. 2010; 33: 159.

[84] Rajasekharreddy P, Rani PU. Biosynthesis and characterization of Pd and Pt nanoparticles using Piper betle L. plant in a photoreduction method. J. Clust. Sci. 2014; 25: 1377-1388.

[85] Soundarrajan C, Sankari A, Dhandapani P., Maruthamuthu S, Ravichandran S, Sozhan G, Palaniswamy N. Rapid biological synthesis of platinum nanoparticles using Ocimum sanctum for water electrolysis applications. Bioproc. Biosyst. Eng. 2012; 35: 827-833.

[86] Al-Radadi NS.Green synthesis of platinum nanoparticles using Saudi's Dates extract and their usage on the cancer cell treatment. Arab. J. Chem. 2019; 12: 330-349.

[87] Mavukkandy MO, Chakraborty S, Abbasi T, Abbasi SA. A clean-green synthesis of platinum nanoparticles utilizing a pernicious weed lantana (Lantana Camara). Am. J. Eng. Applied Sci. 2016; 9: 84-90.

[88] Velmurugan P, Shim J, Kim K, Oh BT. Prunus yedoensis tree gum mediated synthesis of platinum nanoparticles with antifungal activity against phytopathogens. Mater. Lett. 2016; 174: 61-65.

[89] Alshatwi AA, Athinarayanan J, Subbarayan PV. Green synthesis of platinum nanoparticles that induce cell death and G2/M-phase cell cycle arrest in human cervical cancer cells. J. Mater. Sci.: Mater. Med. 2015; $26: 7$.

[90] Ganaie SU, Abbasi T, Abbasi SA. Biomimetic synthesis of platinum nanoparticles utilizing a terrestrial weed Antigonon leptopus. Particul. Sci. Technol. 2018; 36: 681-688.

[91] Manikandan V, Velmurugan P, Park JH, Lovanh N, Seo SK, Jayanthi P, Oh BT. Synthesis and antimicrobial activity of palladium nanoparticles from Prunus yedoensis leaf extract. Mater. Lett. 2016; 185: 335-338.

[92] Zheng B, Kong T, Jing X, Odoom-Wubah T, Li X, Sun D, Li Q. Plant-mediated synthesis of platinum nanoparticles and its bioreductive mechanism. J. Colloid Interf. Sci. 2013; 396: 138-145.

[93] Karim NA, Rubinsin NJ, Burukan MAA, Kamarudin SK. Sustainable route of synthesis platinum nanoparticles using orange peel extract. Int. J. Green Energy. 2019; 16: 1518-1526.

[94] Jeyaraj M, Gurunathan S, Qasim M. A comprehensive review on the synthesis, characterization, and biomedical application of platinum nanoparticles. Nanomater. 2019; 9(12): 1719.

[95] Puja P, Kumar P. A perspective on biogenic synthesis of platinum nanoparticles and their biomedical applications. Spectrochim. Acta Part. 2019; 211: 94-99.

[96] Holton OT, Stevenson JW. The role of platinum in proton exchange membrane fuel cells: evaluation of platinum's unique properties for use in both the anode and cathode of a proton exchange membrane fuel cell. Plat. Metal. Rev. 2013; 57: 259.

[97] Yen CH, Shimizu K, Lin YY, Bailey F, Cheng IF, Wai CM. Chemical fluid deposition of Pt-based bimetallic nanoparticles on multiwalled carbon nanotubes for direct methanol fuel cell application. Ener. Fuel. 2007; 21(4): 2268-2271.

[98] Gupta C, Maheshwari PH, Dhakate SR. Development of multiwalled carbon nanotubes platinum nanocomposite as efficient PEM fuel cell catalyst. Mat. Renew. Sust. Energ. 2016; 5: 2.

[99] Mu Y, Liang H, Hu J, Jiang L, Wan L. Controllable Pt nanoparticle deposition on carbon nanotubes as an anode catalyst for direct methanol fuel cells. J. Phys. Chem. 2005; 109: 22212-22216. 
[100]Li W, Liang C, Zhou W, Qiu J, Zhou Z, Sun G, Xin Q. Preparation and Characterization of Multiwalled Carbon Nanotube-Supported Platinum for Cathode Catalysts of Direct Methanol Fuel Cells. J. Phys. Chem. B. 2003; 107: 6292-6299.

[101]Liu Z, Ling XY, Su X, Lee JY. Carbon-Supported Pt and PtRu Nanoparticles as Catalysts for a Direct Methanol Fuel Cell. J. Phys. Chem. 2004; 108: 8234-8240.

[102]Popovic KD, Lovic JD. Formic acid oxidation at platinum-bismuth catalysts. J. Serb. Chem. Soc. 2015; 80: 12171249.

[103]Jeong H, Kim J.. Insights into the electrooxidation mechanism of formic acid on Pt layers on Au examined by electrochemical SERS. J. Phy. Chem. 2016; 20: 24271-24278.

[104]Park IS, Lee KS, Choi JH, Park HY, Sung YE. Surface structure of platinum modified Au nanoparticles and electrocatalytic activity in formic acid electro-oxidation. J. Phys. Chem. 2007; 111: 19126-19133.

[105]Satterfield CN. Heterogeneous Catalysis in Industrial Practice. Krieger Publication. 1996; 554.

[106]Dunleavy JK. Sulfur as a catalyst poision. Platinum Met. Rev. 2006; 50: 110.

[107]Fu S, Zhu C, Song J, Engelhard M, Xia H, Du D, Lin Y. PdCuPt nanocrystals with multibranches for enzyme-free glucose detection. ACS Appl. Mat. Interf. 2016; 8(34): 22196-200.

[108]Zhai D, Liu B, Shi Y, Pan L, Wang Y, Li W, Zhang R, Yu G. Highly sensitive glucose sensor based on Pt nanoparicles/ polyaniline hydrogel heterostructures. ACS Nano. 2013; 7: 3540-3546.

[109]Yuan SJ, Gu T, Zheng Y, Jiang W, Liang B, Pehkonen SO. Purification of phenol-contaminated water by adsorption with quaternized poly(dimethylaminopropyl methacrylamide)- grafted PVBC microspheres. J. Mater. Chem. A. 2015; 3: 4620-4636.

[110]Tabrizi MA, Shamsipur MJ, Saber R, Sarkar S, Ebrehimi V. A high sensitive visible light-driven photoelectrochemical aptasensor for shrimp allergen tropomyosin detection using graphitic carbon nitride- $\mathrm{TiO}_{2}$ nanocomposite. Biosens. Bioelectron. 2017; 98: 113-118.

[111]Song BB, Zhen YF, Yin HY, Song XC. Electrochemical sensor based on platinum nanoparticles modified graphitelike carbon nitride for detection of phenol. J. Nanosci. Nanotechnol. 2019; 9: 4020-4025.

[112]Pedone D, Moglianetti M, De Luca E, Bardi G and Pompa PP. Platinum nanoparticles in nanobiomedicine. Chem. Soc. Rev. 2017; 46: 4951-4975.

[113]Johnstone TC, Suntharalingam K and Lippard SJ. The next generation of platinum drugs: targeted Pt (II) agents, nanoparticle delivery, and Pt (IV) prodrugs. Chem. Rev. 2016; 116: 3436-3486.

[114]Yin T, Wang Z, Li X, Li Y, Bian K, Cao W, He Y, Liu H, Niu K, Gao D. Biologically inspired self-assembly of bacitracin-based platinum nanoparticles with anti-tumor effects. New J. Chem. 2017; 41: 2941-2948.

[115]Lopez T, Figueras F, Manjarrez J, Bustos J, Alvarez M, Silvestre-Albero J, Rodriguez-Reinoso F, Martínez-Ferre A, Martínez E. Catalytic nanomedicine: a new field in antitumor treatment using supported platinum nanoparticles. In vitro DNA degradation and in vivo tests with C6 animal model on Wistar rats. Eur. J. Med. Chem. 2010; 45: 19821990.

[116]Prasek M, Sawosz E, Jaworski S, Grodzik M, Ostaszewska T, Kamaszewski M, Wierzbicki M and Chwalibog A. Influence of nanoparticles of platinum on chicken embryo development and brain morphology. Nanoscale Res. Lett. 2013; 8: 1-9.

[117]Au, L, Zheng D, Zhou F, Li Z Y, Li X, Xia Y. A quantitative study on the photothermal effect of immuno gold nanocages targeted to breast cancer cells. ACS Nano. 2008; 2(8):1645-1652.

[118]Gharibshahi E, Saion E. Influence of dose on particle size and optical properties of colloidal platinum nanoparticles. Int. J. Mol. Sci. 2012; 13: 14723-14741.

[119]Beyth N, Houri-Haddad Y, Domb A, Khan W, Hazan R. Alternative antimicrobial approach: nano-antimicrobial materials. Evid. Based Complement. Alternat. Med. 2015; 246012.

[120]Zhao Y, Ye C, Liu W, Chen R, Jiang X. Tuning the composition of AuPt bimetallic nanoparticles for antibacterial application. Angew. Chem. Int. Ed. 2014; 53: 8127-8131.

[121]Kebede MA, Imae T, Wu CM, Cheng KB. Cellulose fibers functionalized by metal nanoparticles stabilized in dendrimer for formaldehyde decomposition and antimicrobial activity. Chem. Eng. J. 2017; 311: 340-347.

[122]Gopal J, Hasan N, Manikandan M, Wu HF. Bacterial toxicity/compatibility of platinum nanospheres, nanocuboids and nanoflowers. Sci. Rep., 2013; 3: 1260.

[123]Konieczny P, Goralczyk AG, Szmyd R, Skalniak L, Koziel J, Filon FL, Crosera M, Cierniak A, Zuba-Surma EK, Borowczyk J. Effects triggered by platinum nanoparticles on primary keratinocytes. Int. J. Nanomed. $2013 ;$ 8: 3963.

[124]Bharathan, S., Sundaramoorthy, N. S., Chandrasekaran H. Sub lethal levels of platinum nanoparticle cures plasmid and in combination with carbapenem, curtails carbapenem resistant. Escherichia coli. Sci. Rep. 2019; 9(1): 5305.

[125]Kim YJ, Kim DB, Lee YH, Choi SY, Park JS, Lee SY, Park JW, Kwon HJ. Effects of nanoparticulate saponinplatinum conjugates on 2, 4-dinitrofluorobenzene-induced macrophage inflammatory protein-2 gene expression via 
reactive oxygen species production in RAW 264.7 cells. BMB Rep. 2009; 42: 304-309.

[126]Jawaid P, Rehman MU, Hassan MA, Zhao QL, Li P, Miyamoto Y, Misawa M, Ogawa R, Shimizu T, Kondo T. Effect of platinum nanoparticles on cell death induced by ultrasound in human lymphoma U937 cells. Ultrason. Sonochem. 2016; 31: 206-215.

[127]Jawaid P, Rehman MU, Yoshihisa Y, Li P, Zhao Q, Hassan MA, Miyamoto Y, Shimizu T, Kondo T. Effects of SOD/ catalase mimetic platinum nanoparticles on radiation-induced apoptosis in human lymphoma U937 cells. Apoptosis 2014; 19: 1006-1016.

[128]Ju Y, Kim J. Dendrimer-encapsulated Pt nanoparticles with peroxidasemimetic activity as biocatalytic labels for sensitive colorimetric analyses. Chem. Commun. 2015; 51: 13752-13755.

[129]Clark A, Zhu A, Sun K, Petty HR. Cerium oxide and platinum nanoparticles protect cells from oxidant-mediated apoptosis. J. Nanopart. Res. 2011; 13: 5547-5555.

[130]Kawasaki H, Yamamoto H, Fujimori H, Arakawa R, Inada M, Iwasaki Y. Surfactant-free solution synthesis of fluorescent platinum subnanoclusters. Chem. Commun. 2010; 46: 3759-3761.

[131]Sun Y, Wang J, Li W, Zhang J, Zhang Y, Fu Y. DNA-stabilized bimetallic nanozyme and its application on colorimetric assay of biothiols. Biosens. Bioelectron. 2015; 74: 1038-1046.

[132]Hu X, Saran A, Hou S, Wen T, Ji Y, Liu W, Zhang H, Wu X. Rodshaped Au@PtCu nanostructures with enhanced peroxidase-like activity and their ELISA application. Chin. Sci. Bull. 2014; 59: 2588-2596.

[133]Chen T, Cheng Z, Yi C, Xu Z. Synthesis of platinum nanoparticles templated by dendrimers terminated with alkyl chain. Chem. Comm. J. 2018; 54: 9143-9146.

[134]Chau LY, He Q, Qin A, Yip SP, Lee TM. Platinum nanoparticles on reduced graphene oxide as peroxidase mimetics for the colorimetric detection of specific DNA sequence. J. Mater. Chem. 2016; 4: 4076-4083.

[135]Kwon D, Lee W, Kim W, Yoo H, Shin HC, Jeon S. Colorimetric detection of penicillin antibiotic residues in pork using hybrid magnetic nanoparticles and penicillin class-selective, antibody-functionalized platinum nanoparticles. Anal. Methods. 2015; 7: 7639-7645.

[136]Ji X, Lau HY, Ren X, Peng B, Zhai P, Feng SP, Chan PK. Highly sensitive metabolite biosensor based on organic electrochemical transistor integrated with microfluidic channel and poly (N-vinyl-2-pyrrolidone) capped platinum nanoparticles. Adv. Mater. Technol. 2016; 1: 1600042.

[137]Shi W, Fan H, Ai S, and Zhu L.. Honeycomb-like nitrogen-doped porous carbon supporting Pt nanoparticles as enzyme mimic for colorimetric detection of cholesterol. Sens. Actuators B Chem. 2015; 221: 1515-1522.

[138]Wu LL, Wang LY, Xie ZJ, Pan N, Peng CF. Colorimetric assay of 1-cysteine based on peroxidase-mimicking DNAAg/Pt nanoclusters. Sens. Actuator B-Chem. 2016; 235: 110-116.

[139]He SB, Wu GW, Deng HH, Liu AL, Lin XH, Xia XH, Chen W. Choline and acetylcholine detection based on peroxidase-like activity and protein antifouling property of platinum nanoparticles in bovine serum albumin scaffold. Biosens. Bioelectron. 2014; 62: 331-336.

[140]Gao F, Du L, Zhang Y, Zhou F, Tang D. A sensitive sandwich-type electrochemical aptasensor for thrombin detection based on platinum nanoparticles decorated carbon nanocages as signal labels. Biosens. Bioelectron. 2016; 86: 185193.

[141]Yang ZH, Zhuo Y, Yuan R, Chai YQ. A nanohybrid of platinum nanoparticles-porous ZnO-hemin with electrocatalytic activity to construct an amplified immunosensor for detection of influenza. Biosens. Bioelectron. 2016; 78: $321-327$.

[142]Dutta G, Nagarajan S, Lapidus LJ, Lillehoj PB. Enzyme-free electrochemical immunosensor based on methylene blue and the electro-oxidation of hydrazine on Pt nanoparticles. Biosens. Bioelectron. 2017; 92: 372-377.

[143]Gao Z, Xu M, Hou L, Chen G, Tang D. Irregular-shaped platinum nanoparticles as peroxidase mimics for highly efficient colorimetric immunoassay. Anal. Chim. Acta. 2013; 776: 79-86.

[144]Wang Z, Yang X, Feng J, Tang Y, Jiang Y, He N. Label-free detection of DNA by combining gated mesoporous silica and catalytic signal amplification of platinum nanoparticles. Analyst. 2014; 139: 6088-6091.

[145]Carmona U, Zhang L, Li L, Munchgesang W, Pippel E and Knez M. Tuning, inhibiting and restoring the enzyme mimetic activities of Pt-apoferritin. Chem. Commun. 2014; 50: 701-703.

[146]Bott-Neto JL, Asset T, Maillard F, Dubau L, Ahmad Y, Guérin K, Chatenet M. Utilization of graphitized and fluorinated carbon as platinum nanoparticles supports for application in proton exchange membrane fuel cell cathodes. J. Power Sources. 2018; 404: 28-38.

[147]Hussein HE, Amari H, Macpherson JV. Electrochemical synthesis of nanoporous platinum nanoparticles using laser pulse heating: application to methanol oxidation. ACS Catal. 2017; 7: 7388-7398.

[148]Sha R, Badhulika, S. Binder free platinum nanoparticles decorated graphene-polyaniline composite film for high performance supercapacitor application. Electrochim. Acta. 2017; 251: 505-512.

[149].Kakaei K. High efficiency platinum nanoparticles based on carbon quantum dot and its application for oxygen reduction reaction. Int. J. Hydrogen Energ. 2017; 42: 11605-11613. 
[150]Zhang L, Li S, Xin J, Ma H, Pang H, Tan L, Wang X. A non-enzymatic voltammetric xanthine sensor based on the use of platinum nanoparticles loaded with a metal-organic framework of type MIL-101 (Cr). Application to simultaneous detection of dopamine, uric acid, xanthine and hypoxanthine. Microchim. Acta. 2019; 186: 9.

[151]Baskaran B, Muthukumarasamy A, Chidambaram S, Sugumaran A, Ramachandran K, Manimuthu TR. Cytotoxic potentials of biologically fabricated platinum nanoparticles from Streptomyces sp. on MCF-7 breast cancer cells. IET Nanobiotechnol. 2016; 11: 241-246.

[152]Xiao X, Oswald JT, Wang T, Zhang W, Li W. Use of anticancer platinum compounds in combination therapies and challenges in drug delivery. Curr. Med. Chem. 2018.

[153]Browning RJ, Reardon PJT, Parhizkar M, Pedley RB, Edirisinghe M, Knowles JC, Stride E. Drug delivery strategies for platinum-based chemotherapy. ACS nano. 2017; 11: 8560-8578.

[154]Bendale Y, Bendale V, Paul S. Evaluation of cytotoxic activity of platinum nanoparticles against normal and cancer cells and its anticancer potential through induction of apoptosis. Integr. Med. Res. 2017; 6: 141-148.

[155]Leist M, Jäättelä M. Four deaths and a funeral: from caspases to alternative mechanisms. Nat. Rev. Mol. Cell Biol. 2001; 2: 589-598.

[156]Loan TT, Do LT, Yoo H. Platinum nanoparticles induce apoptosis on Raw 264.7 macrophage cells. J. Nanosci. Nanotechno. 2018; 18: 861-864.

[157]Almeer RS, Ali D, Alarifi S, Alkahtani S, Almansour M. Green platinum nanoparticles interaction with HEK293 cells: Cellular toxicity, apoptosis, and genetic damage. Dose-Response. 2018; 16. 